\title{
TINGKAT INSIDENSI PEMOTONGAN SAPI BETINA BUNTING DAN KARAKTERISTIK FETUS DI RUMAH POTONG HEWAN KOTA AMBON
}

\author{
D. F. Souhoka*), Astri. D. Tagueha, Rajab \\ Jurusan Peternakan Fakultas Pertanian, Universitas Pattimura \\ Jln. Ir. M. Putuhena, Kampus Poka, Ambon 97233 \\ *Email : demisouhoka@gmail.com
}

\begin{abstract}
ABSTRAK
Penelitian dilakukan bertujuan untuk mengetahui tingkat insidensi pemotongan sapi betina bunting dan karakteristik fetus sapi yang dibuang di RPH Kota Ambon. Metode penelitian menggunakan pendekatan studi kasus. Variabel yang diamati meliputi jumlah sapi yang dipotong, karakteristik betina yang dipotong (jumlah, berat badan dan asal), dan karakteristik fetus sapi yang dibuang (jumlah, jenis kelamin, dan panjang badan). Data dianalisis secara diskriptif menggunakan grafik dan table. Uji t dilakukan untuk membandingkan ukuran tubuh fetus berdasarkan jenis kelaminnya. Hasil penelitian menunjukan tingkat insidensi pemotongan sapi betina bunting 34\%, telah melampaui batas toleransi $12 \%$. Ditemukan 53 fetus yang terdiri dari 30 fetus betina dan 23 fetus jantan. Rata-rata berat fetus sapi 2160,17 gram dan rata-rata panjang tubuh $32,68 \mathrm{~cm}$.
\end{abstract}

Kata kunci : Insidensi pemotongan, betina bunting, fetus, rumah potong hewan

\section{THE INCIDENCE RATE OF PREGNANT COWS SLAUGHTERED AND FOETAL CHARATERISTICS AT THE AMBON TOWN ABATTOIRS}

\begin{abstract}
The objectives of this research were to investigate the incidence of pregnant cows slaughtered and to explore incidence level of foetal wastage at the abattoirs in Ambon city. Data collection were held at the abattoirs from three weeks observations. The notion of the research was a case study investigation. The variables were number of cattle slaughtered, characteristics of cows slaughtered [number, body weight, and origin of cows], and characteristics of foetal wastage [number, sex, body weight, and body length]. Data were descriptively analyzed and the graphically presented. t-test was also used to compare body measures of foetuses based on its sex. The results showed that incidence of pregnant cows slaughtered was $34 \%$ which is higher than the tolerance limit $12 \%$. There were 53 fetuses found consisted of 30 females and 23 males. Average fetuses weight was 2160.17 grams and $32.68 \mathrm{~cm}$ body length.
\end{abstract}

Key words: Slaughtered incidence, pregnant cows, foetal, abattoir

\section{PENDAHULUAN}

Program peningkatan populasi ternak dilakukan melalui peningkatan kelahiran, peningkatan produksi dan produktivitas, pengendalian pemotongan betina produktif, pengendalian penyakit dan penyediaan bibit bermutu (Dirjen Peternakan dan Kesehatan Hewan, 2019 ; Ariningsih, 2014). Program tersebut belum membuahkan hasil yang signifikan, terutama pada temuan pemotongan sapi betina produktif yang terjadi di Rumah Potong Hewan (RPH) (Tawaf dkk., 2013 ; Rasminati dkk., 2009). Menurut UU Nomor 41 Tahun 2014 menyebutkan pemotongan betina produktif hanya diijinkan untuk kasus-kasus tertentu, misalnya kebutuhan penelitian, atau tujuan pengendalian dan penanggulangan penyakit. Kenyataannya di lapangan tidaklah demikian, ternak betina bunting masih disembelih untuk pemenuhan kebutuhan konsumen. Hingga kini belum ada pihak terlapor yang diberi sanksi peringatan secara tertulis, dikenakan denda, penghentian aktifitas produksi, pencabutan ijin hingga sanksi kurungan atau pembayaran denda.

Pemotongan betina produktif berstatus bunting merupakan fenomena umum dihampir semua rumah potong hewan (RPH), dan diperkirakan terdapat pemotongan secara nasional terhadap 150.000 sampai 200.000 ekor sapi betina produktif per tahun (Dwiyanto, 2011 ; Priyanto, 2011). Sebagaimana dilaporkan Soejosopoetro (2011) bahwa terdapat pemotongan 199 ekor sapi betina dalam kurun waktu 2 bulan di RPH Malang. Persentase lebih tinggi ditemukan di RPH Makassar, yaitu 200 sampai 300 ekor per minggu (Isnaenul, 2016). Lebih lanjut Aritonang (2017) melaporkan rata-rata peningkatan angka pemotongan 
per bulan di Provinsi Jambi mencapai 20,99 \% dan $17,53 \%$ berturut-turut untuk sapi dan kerbau betina yang masih memiliki kemampuan untuk berreproduksi lagi.

Berbagai faktor berkontribusi diperkirakan cukup kompleks yaitu berasal dari peternak, rantai pemasaran, hingga pengawasan oleh institusi terkait yang berwenang. Hal lainnya adalah tekanan sosial dan kemudahan akses penjualan merupakan faktor yang mendominasi di tingkat peternak (Mappigau dkk., 2012). Implementasi UU Nomor 14 tahun 2014 pasal 18 ayat 4 sampai 6 melalui tindakan sosialisasi, monitoring, dan evaluasi yang tidak pernah dilakukan oleh instansi berwewenang juga menjadi faktor penyebabnya (Isnaenul, 2016).

Hingga saat ini belum ada kajian empirik tentang pemotongan betina bunting sebagai salah satu indikator kasus pemotongan betina produktif di RPH Ambon. Penelitian ini bertujuan untuk mengetahui tingkat insidensi pemotongan sapi betina bunting dan tingkat insidensi pembuangan fetus sapi serta karakteristiknya di RPH Kota Ambon.

\section{BAHAN DAN METODE}

Penelitian dilaksanakan di rumah potong hewan (RPH) Kota Ambon selama dua bulan yaitu pada bulan september sampai oktober 2018, menggunakan metode studi kasus dengan teknik investigasi. Observasi dilakukan setiap hari dengan mencatat jumlah sapi yang dipotong, pemeriksaaan saluran reproduksi betina yang dipotong. Fetus yang ditemukan ditimbang dan pengukuran panjang fetus untuk mengidentifikasi umur dan jenis kelamin fetus.

Variabel yang diamati meliputi asal sapi, jumlah pemotongan, tingkat insidensi pemotongan betina bunting, tingkat insidensi pembuangan fetus, dan karakteristik fetus.

Data yang dikumpulkan dikualifikasi menurut variabel yang diteliti, dianalisis secara dekskriptif. Insidensi pemotongan sapi betina bunting (IPSBB) didapat dari jumlah betina bunting dibagi dengan total pemotongan dikali seratus.

$$
I P S B B=\frac{\text { jumlah betina bunting }}{\text { total pemotongan }} \times 100 \%
$$

Insidensi penemuan fetus (IPF) didapat dari jumlah fetus dibagi dengan total pemotongan kali seratus persen.

$$
I P F=\frac{\text { jumlah fetus }}{\text { total pemotongan }} \times 100 \%
$$

Selanjutnya dilakukan uji $\mathrm{t}$ untuk membandingkan ukuran tubuh fetus berdasarkan jenis kelamin. Analisis data dengan bantuan software MINITAB versi 17.0.

Tabel 1. Asal Sapi yang Dipotong Di RPH Kota Ambon

\begin{tabular}{lcccccc}
\hline \multirow{2}{*}{ Asal sapi } & \multicolumn{2}{c}{ Jantan } & \multicolumn{2}{c}{ Betina } & \multicolumn{2}{c}{ Jumlah } \\
\cline { 2 - 7 } & Ekor & $\%$ & Ekor & $\%$ & Ekor & $\%$ \\
\hline Pulau Seram & 89 & 22,8 & 115 & 29,4 & 204 & 52,2 \\
Pulau Buru & 67 & 17,1 & 120 & 30,7 & 187 & 47,8 \\
\hline Total & 156 & 39,9 & 235 & 60,1 & 391 & 100 \\
\hline
\end{tabular}

\section{HASIL DAN PEMBAHASAN}

Dinamika aktivitas pemotongan sapi di Rumah Potong Hewan (RPH) Kota Ambon berjalan seiring dengan aktivitas ekonomi masyarakat terkait pemenuhan kebutuhan daging sapi sehari-hari di pasar yang kian meningkat sehingga jumlah pemotongan sapi pun meningkat terutama saat hari raya keagamaan.

\section{Asal Sapi yang Dipotong}

Hasil penelitian memperlihatkan persentase sapi terbanyak didatangkan dari Pulau Seram yaitu sebesar $52,2 \%$, sedangkan Pulau Buru sebesar 47,8 \% dari total sapi yang dipotong selama waktu penelitian (Tabel 1). Persentase betina yang didatangkan dari kedua pulau tersebut ke RPH kota Ambon untuk dipotong hampir berimbang, masing-masing Pulau Buru 30,7 \% dan Pulau Seram 29,4 \% dari total sapi yang didatangkan selama waktu penelitian.

RPH Kota Ambon melayani pemotongan Sapi yang didatangkan dari berbagai pulau di sekitar pulau
Ambon. Selama masa penelitian ini berlangsung total sebanyak 391 ekor Sapi yang dipotong, dengan rincian sapi yang berasal dari pulau seram sebanyak 204 ekor $(52,2 \%)$ dan Pulau Buru 187 ekor (47,8 \%). Kedua pulau tersebut merupakan daerah pengembangan sapi potong di Propinsi Maluku karena potensi lahan dan ketersediaan pakan ternak berupa rumput dan limbah pertanian untuk pakan ternak yang memadai. Terlebih lagi Pulau Buru yang karakteristik pertaniannya yang berbasis sawah irigasi yang dilakukan oleh para transmigran asal Pulau Jawa, ketersediaan jerami dan dedak padi tersedia sebagai pakan ternak selain rumput dan hijauan pakan ternak lainnya (Alam dkk., 2014).

Jumlah sapi betina yang didatangkan ke RPH kota Ambon dari kedua pulau tersebut cukup berimbang, yang dapat diartikan bahwa kesadaran untuk tidak menjual sapi betina pun masih sama rendahnya. Selain itu dapat pula diartikan bahwa kebutuhan dan permasalahan yang dihadapi oleh peternak dari kedua pulau tersebut, terkait urgensi atau pun keterpaksaan penjualan sapi betina betina mungkin 
pula mirip yakni persoalan kebutuhan uang tunai untuk membiayai usaha peternakan dan rumah tangganya.

\section{Angka Pemotongan Sapi}

Tingkat pemotongan sapi jantan, betina, dan betina bunting di RPH Kota Ambon selama periode 3 minggu pengamatan seperti tertera pada Tabel 2. Hasil penelitian menunjukkan bahwa tingkat pemotongan sapi betina lebih tinggi dibandingkan sapi jantan. Jumlah sapi betina baik bunting maupun tidak bunting yang dipotong cenderung fluktuatif dari total sebanyak
235 ekor, dan terlihat pada minggu pertama sebanyak 81 ekor, minggu kedua 82 ekor dan pada minggu ketiga sebanyak 72 ekor.

Pemotongan sapi jantan meskipun lebih sedikit jumlahnya juga fluktuatif, dari 52 ekor pada minggu I, 50 ekor di minggu II, dan 54 ekor di minggu III atau total sebanyak 156 ekor. Sebaliknya, pada sapi betina bunting kecenderungannya justru meningkat yaitu dari 23 ekor di minggu I (14,39\%), menjadi 28 ekor di minggu II (17.5\%) dan 30 ekor di minggu III (19.2\%) (Tabel 2).

Tabel 2. Rekapitulasi Data Pemotongan Sapi Selama Bulan Oktober di RPH Kota Ambon

\begin{tabular}{ccccc}
\hline Minggu & Jumkah Pemotongan (ekor) & Jumlah jantan (ekor) & \multicolumn{2}{c}{ Jumlah betina (ekor) } \\
\cline { 3 - 5 } & & & Bunting & Tidak bunting \\
\hline I & 133 & 52 & 23 & 58 \\
II & 132 & 50 & 28 & 54 \\
III & 126 & 54 & 30 & 42 \\
\hline Total & 391 & 156 & 81 & 154 \\
\hline
\end{tabular}

Persentase pemotongan sapi jantan dan betina berdasarkan data penelitian yaitu $40 \%$ dan $60 \%$. Hasil penelitian membuktikan bahwa pemotongan sapi betina memang telah terjadi di RPH Kota Ambon dan jumlahnya sangat besar. Total pemotongan sapi betina selama 3 minggu masa pengamatan adalah 235 ekor atau $60 \%$ dari jumlah keseluruhan sapi yang dipotong. Hasil ini menunjukan terdapat 78 ekor sapi betina yang dipotong tiap minggu atau 11 ekor setiap harinya, sementara pemotongan sapi jantan lebih rendah, yaitu 52 ekor tiap minggu atau 2 ekor setiap harinya. Temuan ini sungguh merupakan suatu ironi ditengah upaya pemerintah mengampanyekan implementasi UU No. 41 Tahun 2014 dalam hal pelarangan pemotongan sapi betina produktif untuk mendukung produktifitas sapi potong dan swasembada daging di Indonesia.

Hasil pengamatan di lapangan menunjukkan harga penjualan sapi betina dan betina bunting lebih murah dibandingkan penjualan sapi jantan sehingga pedagang akan lebih gencar berkunjung di usaha peternakan kecil untuk menggoda peternak yang membutuhkan uang tunai guna membiayai berbagai keperluan keluarga. Berdasarkan hasil wawancara dengan para tukang jagal, diketahui bahwa sapi-sapi jantan sengaja dipasok untuk penjualan pada hari-hari tertentu, misalnya menjelang Idul Fitri atau Idul Adha yang harganya 2-3 kali lebih tinggi dari hari biasa. Sapisapi tersebut biasanya ditempatkan di lokasi penampungan sementara karena lokasi RPH tidak memungkinkan, selain itu juga menghindari kecurigaan dari petugas dinas setempat. Strategi ini akan mendatangkan keuntungan berlipat ganda bagi pedagang pengumpul. Fayerni dan Muchenje (2013) menyatakan bahwa kondisi keuangan para petani dan ketidakpedulian terhadap status kebuntingan ternak merupakan alasan penjualan dan pemotongan sapi betina bunting di antara berbagai alasan lainnya seperti depresi atau tekanan di pasar ternak sapi, tingginya permintaan pasar dan kepercayaan takhayul tentang penggunaan atau konsumsi daging betina bunting.

Purba dan Hadi (2012) mensinyalir bahwa pemberlakuan pelarangan pemotongan sapi betina produktif menjadi tidak efektif karena terlalu kuatnya posisi bisnis pedagang besar di daerah. Pemerintah daerah tidak bisa berbuat banyak dalam menyikapi permasalahan ini karena terbatasnya dana pemerintah daerah untuk membeli ternak sapi betina produktif tersebut. Jalan lain yang bisa ditempuh pemerintah adalah memberikan insentif yang memadai bagi peternak untuk menunda penjualan betina produktif terutama hingga betina bunting selesai partus.

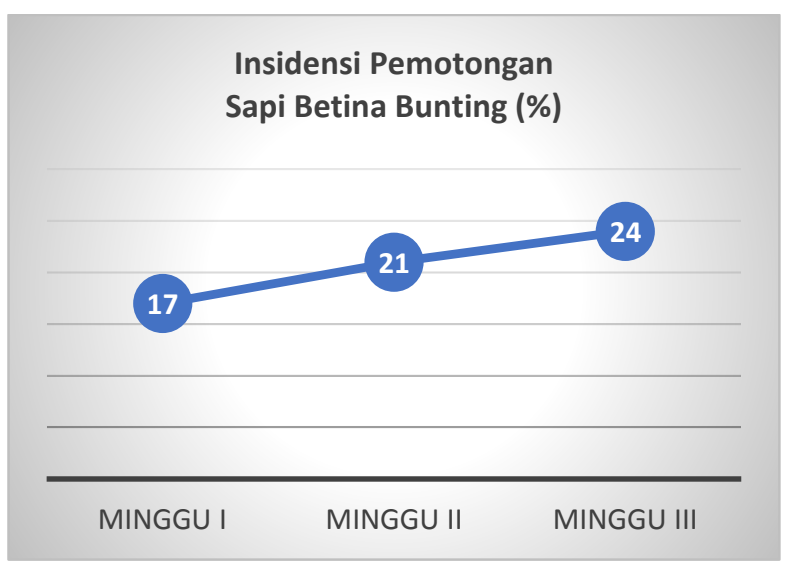

Gambar 1. Tingkat Insidensi Pemotongan Sapi Betina Bunting di RPH Kota Ambon

\section{Tingkat Insidensi Pemotongan Sapi Betina}

Secara keseluruhan, tingkat insidensi pemotongan sapi betina bunting selama periode penelitian mencapai $21 \%$ jika dirinci per minggu, terlihat ada peningkatan dari $17 \%$ pada minggu I mencapai $24 \%$ di minggu III (Gambar 1). Walaupun menunjukan kecenderungan serupa, ada perbedaan 
angka pemotongan pada tiap minggu seperti diuraikan pada Gambar 1.

Penelitian ini juga membuktikan bahwa cukup banyak sapi betina bunting yang dipotong di RPH Kota Ambon, jumlahnya mencapai 81 ekor selama periode pengamatan dengan tingkat insidensi $60 \%$. Data ini dapat diartikan pula ada 27 ekor sapi betina bunting per minggu atau 4 ekor sapi betina bunting yang dipotong tiap hari. Jika sapi- sapi tersebut berada pada kisaran umur 2-3 tahun, berarti masih ada 3 tahun laginya untuk bereproduksi. Dengan demikian, pemotongan 81 ekor betina bunting tersebut berarti memusnahkan 324 ekor generasi berikutnya. Apabila data tersebut diprediksikan dalam 1 tahun dengan catatan ada 45 minggu efektif untuk bekerja, maka potensi pemotongan betina bunting di RPH mencapai 1215 ekor sapi betina bunting per tahun dan demikian juga memusnahkan 3645 ekor generasi yang dapat dihasilkan selama masa produktifitasnya.

Hasil penelitian juga menunjukkan rasio pemotongan sapi betina bunting per total pemotongan mencapai $21 \%$. Angka ini telah melampaui batas toleransi yaitu $12 \%$ seperti yang dikemukakan Agung dkk. (1981). Insidensi pemotongan sapi bunting yang sangat besar di RPH Kota Ambon tersebut dengan sendirinya juga berimplikasi pada keraguan tentang efisiensi inspeksi antemortem yang dilakukan oleh petugas kesehatan hewan pemerintah kota dan keseriusan pemerintah kota dalam melestarikan sumberdaya genetik sapi dan peningkatan produktifitas sapi di provinsi Maluku. Tentunya temuan ini secara harafiah menggambarkan inefisiensi peran petugas pemerintah dalam pelaksanaan fungsi pengawasan. Hasil wawancara dengan beberapa petugas inspeksi diketahui bahwa kedisiplinan dalam mematuhi waktu pemotongan dan waktu inspeksi juga merupakan salah satu hambatan dalam pelaksanakan inspeksi dan pencatatan. Menurut Mossberger dan Wolman (2003) inspeksi atau monitoring dimaksudkan untuk mengetahui kendala-kendala serta mengantisipasi masalah yang timbul atau akan timbul sehingga dapat diambil tindakan sedini mungkin.

Pemotongan ternak sapi bunting bukan saja tidak etis namun juga tidak ekonomis mengingat potensi ekonomi anak sapi setelah umur sapih dapat dijual (Swai et al., 2015). Kondisi keuangan para petani dan ketidakpedulian terhadap status kebuntingan ternak merupakan alasan penjualan dan pemotongan sapi betina bunting di antara alasan lainnya seperti depresi atau tekanan di pasar ternak sapi, tingginya permintaan, dan kepercayaan takhayul tentang panggunaan atau konsumsi daging betina bunting ataupun fetus (Fayerni dan Muchenje, 2013). Alhaji (2011) mengatakan bahwa dampak dari pemotongan sapi betina bunting yakni berkurangnya populasi serta masyarakat (pembeli) dipaksa untuk mengkonsumsi daging berkualitas rendah. Alhaji et al. (2015) menyatakan bahwa kerugian keuangan akibat pemotongan induk sapi bunting mencapai rata-rata per tahun sekitar US \$290.000.

\section{Tingkat Insidensi Penemuan Fetus Sapi}

Hasil penelitian menunjukan tingkat insidensi penemuan fetus sapi di RPH Kota Ambon selama periode pengamatan meningkat dari 0,28 atau $28 \%$ pada minggu I ke 0,34 atau $34 \%$ pada minggu kedua, dan 0,41 atau $41 \%$ pada minggu ketiga (Gambar 2). Semua fetus yang ditemukan akan dibuang karena sudah dianggap sebagai limbah dari RPH. Terkait penyebab fenomena peningkatan jumlah limbah fetus dari pemotongan induk bunting tersebut di RPH Kota Ambon perlu ada penelitian lebih detail tentang hal itu. Faktor desakan keuangan pada waktu-waktu peternak membutuhkan uang mungkin saja menjadi pendorong utama.

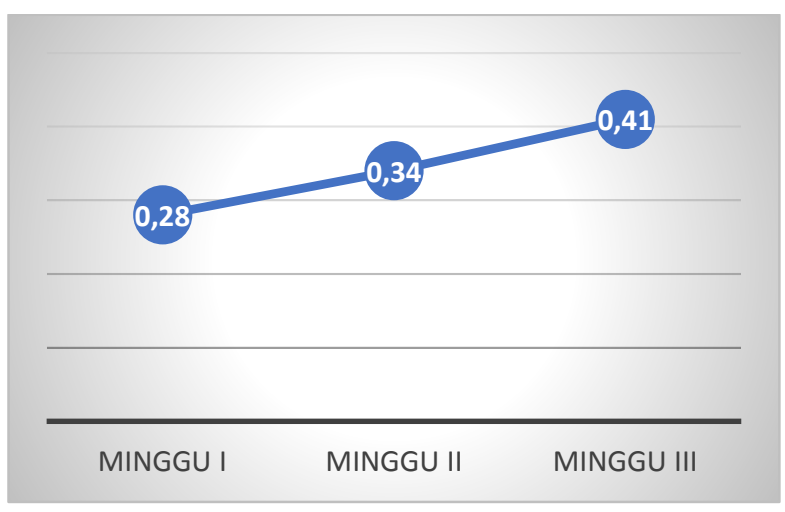

Gambar 2. Tingkat Insidensi Penemuan Fetus Sapi Di RPH Kota Ambon

Menurut Alhaji (2011) dan Alhaji et al. (2015), kecenderungan penjualan betina bunting untuk dipotong pada musim hujan cenderung berkaitan dengan ketersediaan pakan yang cukup yang mempengaruhi postur dan bobot badan jual induk, sedangkan induk bunting dijual pada musim kering sebagai konpensasi kesukaran pakan ternak dan untuk menutup ongkos pakan ternak. Cadmus and Adesokan (2010)menjelaskan pada musim panas di Nigeria terjadi kekeringan dan pakan ternak susah didapat, sehingga peternak berkeputusan untuk menjual ternak betina buntingnya sebelum mati akibat kelaparan dan uangnya dapat digunakan untuk rumah tangganya menutupi kesukaran hidup selama kekeringan.

\section{Karakteristik Fetus Sapi yang Dibuang}

Hasil penelitian menunjukan bahwa terjadi pemotongan 81 ekor sapi betina bunting, dengan demikian dipastikan terdapat 81 ekor fetus yang dibuang sebagai limbah (Tabel 3). Dari jumlah tersebut 53 ekor fetus berhasil diidentifikasi jenis kelaminnya, yakni 30 ekor berjenis kelamin betina sedangkan jantan 23 ekor. Jumlah sapi bunting yang dipotong di RPH Kota Ambon yang telah melalui ambang batas toleransi (> $12 \%$ ) tentu juga menyisakan limbah fetus yang sangat banyak juga (81 ekor) bagi lingkungan sekitar RPH. Cadmus and Adesokan (2010) menyatakan jika pelayanan di RPH dan inspeksi dilakukan dengan baik 
maka secara dini dapat dicegah pemotongan ternak betina bunting dan mencegah adanya limbah fetus.

Berdasarkan fetus yang teridentifikasi jenis kelaminnya, lebih banyak ditemukan fetus betina (30) ekor dibandingkan fetus jantan (23) ekor. Artinya, selama kurun waktu pengamatan yanghanya tiga minggu sebanyak 53 ekor bakal anak sapi telah dibunuh dan dibuang, padahal bakal anakan tersebut jika indukannya dipelihara sampai melahirkan dan demikian pula anaknya diselamatkan dan dipelihara hingga umur lepas sapih, akan berkontribusi dalam menambah kekayaan plasma nutfah sapi lokal dan lebih bernilai ekonomis serta tidak berdampak pada polusi lingkungan oleh darah dan bangkai ternak.

Tabel 3. Jumlah Fetus Sapi yang Dibuang di RPH Kota Ambon

\begin{tabular}{ccccc}
\hline Minggu & $\begin{array}{c}\text { Jumlah fetus } \\
\text { (ekor) }\end{array}$ & $\begin{array}{c}\text { Fetus jantan } \\
\text { (ekor) }\end{array}$ & $\begin{array}{c}\text { Fetus betina } \\
\text { (ekor) }\end{array}$ & $\begin{array}{c}\text { Kelamin tidak } \\
\text { teridentifikasi } \\
\text { (ekor) }\end{array}$ \\
\hline I & 23 & 3 & 11 & 9 \\
II & 28 & 10 & 9 & 9 \\
III & 30 & 10 & 10 & 10 \\
\hline Jumlah & 81 & 23 & 30 & 28 \\
\hline
\end{tabular}

Tabel 4. Rata-Rata Pengukuran Fetus yang Dibuang Pada RPH Kota Ambon

\begin{tabular}{|c|c|c|c|c|}
\hline \multirow[t]{2}{*}{ Jenis kelamin } & \multicolumn{2}{|c|}{ Bobot badan (gram) } & \multicolumn{2}{|c|}{ Panjang badan $(\mathrm{cm})$} \\
\hline & Rata-rata & t-test & Rata-rata & t-test \\
\hline Jantan & 2732,63 & $-1,52^{\text {ts }}$ & 40,22 & $-1,39^{\text {ts }}$ \\
\hline Betina & 4282,47 & & 46,30 & \\
\hline
\end{tabular}

ts : tidak signifikan $(\mathrm{p}>0,05)$

Tabel 5. Perbedaan Umur Gestasi, Berat Badan, dan Panjang Badan Fetus yang Jenis Kelaminnya Diidentifikasi dan Tidak Teridentifikasi

\begin{tabular}{cccc}
\hline Jenis kelamin & $\begin{array}{c}\text { Rata-rata umur gestasi } \\
(\text { bln })\end{array}$ & $\begin{array}{c}\text { Rata-rata berat badan } \\
(\text { gram })\end{array}$ & $\begin{array}{c}\text { Rata-rata panjang } \\
\text { badan }(\mathrm{cm})\end{array}$ \\
\hline Jantan & 4,89 & 2732,63 & 40,22 \\
Betina & 5,37 & 4282,47 & 46,3 \\
Tidak teridentifikasi & 1,68 & 40,8 & 7,96 \\
\hline
\end{tabular}

Rata-rata bobot fetus yang dibuang di RPH adalah 2141,17 gram dengan panjang badan $30,33 \mathrm{~cm}$. Data bobot dan panjang fetus tersebut menggambarkan stadium fetus selama masa kebuntingan. Rata-rata bobot badan dan panjang badan fetus per jenis kelamin seperti terlihat pada Tabel 4. Rataan bobot badan dan panjang fetus jantan berturut-turut 2732,63 gram dan $40,22 \mathrm{~cm}$, sedangkan pada fetus betina rataannya sebesar 4282,47 gram untuk berat badan dan $46,30 \mathrm{~cm}$ untuk panjang badan (Tabel 4). Hasil analisis statistik menunjukkan tidak terdapat hubungan antara jenis kelamin dengan berat badan fetus yang dibuang di RPH Kota Ambon ( $p>0,05$ ), demikian pula tidak ada korelasi antara jenis kelamin dengan panjang badan fetus ( $p>0,05)$.

Merujuk pada kajian Lyne (1960) tentang perkembangan pre-natal dari spesies Bos taurus dan pertimbangan bahwa maksimal bobot badan sapi bali pada saat lahir adalah $50 \%$ dari bobot spesies Bos taurus pada umumnya, maka diperkirakan rata-rata fetus yang dibuang berasal dari umur kebuntingan 5-6 bulan. Sedangkan secara spesifik, rata-rata umur fetus berdasarkan jenis kelamin yaitu, 4,89 bulan untuk fetus jantan dan 5,37 bulan untuk fetus betina (Tabel 5).
Selain 53 fetus yang diidentifikasi jenis kelaminnya, terdapat juga 28 ekor yang tidak berhasil diidentifikasi. Berdasarkan perhitungan rata-rata berat badan (Tabel 5) diperkirakan kelompok fetus masih dalam bulan ke-2 perkembangan pre-natal.

Mao et al. (2008) menyatakan bahwa pertumbuhan fetal dan perkembangannya merupakan suatu proses kompleks yang bekaitan dengan interaksi antara potensi genetik, faktor lingkungan, dan suplai nutrisi selama kebuntingan induk sapi serta berbeda pula menurut jenis kelamin fetus. Selanjutnya dikatakannya, perkembangan berat badan berawal pada umur kebuntingan induk sapi 3 bulan hingga lahir, sedangkan perkembangan organ tubuh mulai dari usia kebuntingan 3 bulan hingga 9 bulan. Misalnya perkembangan hati dan jantung fetus sapi perkembangannya cepat pada tahapan ketiga periode kebuntingan. Perbedaan jenis kelamin fetus dapat tampak pada usia kebuntingan induk sapi 60 hari.

Hasil penelitian menunjukan, fetus asal sapi betina yang dipotong dan akhirnya menjadi limbah berada pada stadium perkembangan pre-natal yang bervariasi, mulai dari awal kebuntingan hingga yang siap lahir. Dengan demikian, terbukti bahwa 
pemotongan sapi betina bunting di RPH secara langsung telah mengurangi populasi sapi. Krog et al. (2018) menyatakan penentuan umur fetus dapat diketahui secara fetometrik dari panjang badan, lebar kepala, panjang kerpala, dapat berbeda hasilnya menurut perbadaan jenis kelamin. Lebih lanjut Taylor $e t$ al. (2017) mengatakan bahwa banyak faktor yang mempengaruhi berat dan panjang fetus yang dihasilkan seekor ternak induk, diantaranya adalah faktor nutrisi induk, kondisi suhu lingkungan, paritas, dan genotif induk. Misalnya, pembatasan nutrisi yang berlebihan bagi induk selama paruh waktu setengah hingga $2 / 3$ akhir kebuntingan dapat mengurangi pertumbuhan dan perkembangan fetus. Induk sapi muda akan berespons berbeda dengan induk sapi tua terhadap pembatasan nutrisi yang berakibat pada respons yang berbeda pula pada pertumbuhan dan perkembangan fetus.

\section{SIMPULAN DAN REKOMENDASI}

Berdasarkan hasil penelitian, beberapa hal yang dapat disimpulkan yaitu : (1) tingkat insidensi pemotongan sapi betina bunting di RPH Kota Ambon cenderung meningkat setiap minggunya dan telah melampaui batas toleransi yaitu $12 \%$. Begitu banyak induk bunting yang dipotong mengindikasikan lemahnya pemeriksaan antemortem pada sapi-sapi yang hendak dipotong; dan (2) tingkat insidensi penemuan fetus sapi di RPH Kota Ambon cenderung meningkat tiap minggu. Jika dibandingkan per jumlah sapi terpotong, maka insidensi penemuan fetus sapi sebesar 0,21 atau $21 \%$.

Perlu adanya pengawasan ketat oleh pihak veteriner selama proses pemeriksaan antemortem pada semua sapi-sapi yang akan dipotong di RPH Kota Ambon, serta perlu penegakan aturan dan sanksi terhadap pelaku pemotongan sapi betina produktif dan induk bunting, dan juga bagi petugas pemerintah yang tidak disiplin dalam melakasanakan tugasnya untuk pencatatan dan inspeksi ternak di RPH Kota Ambon.

\section{DAFTAR PUSTAKA}

Alam, A., S. Dwijatmiko, dan W. Sumekar. 2014. Faktor-Faktor yang Mempengaruhi Aktivitas Budidaya Ternak Sapi Potong Di Kabupaten Buru. Agrinimal. 4(1): 28-37.

Agung, K., S. Djojowidagdo, Arito, dan Sunardi. 1981. Inventarisasi Polusi Supply Ternak Potong. Kerja Sama Dinas Peternakan Daerah Tingkat I Jawa Tengah Fakultas Peternakan Universitas Gajah Mada, Yogyakarta.

Alhaji, N. B. 2011. Prevalence and Economic Implication of Calf Foetal Wastage in An Abatoir in On Northcentral Nigeria. Trop Anim Health Prod. 43:587-590.

Alhaji, N. B., L. A. Odetokun, A. Shittu, J. Onyango, U. M. Abubakar, I. A. Muraina, F. O. Fasina, and H. S. Lee. 2015. Time-Series Analysis of Ruminant Foetal Wastage at A Slaughterhouse in Northcentral Nigeria Between 2001 and 2012. Onderstepoort Journal of Veterinary Research. 82(1): 10101023. DOI: $10.4102 /$ jojr.v82il.1010.

Ariningsih, E. 2014. Kinerja Kebijakan Swasembada Daging Sapi Nasional. Forum Penelitian Agro Ekonomi. 32(2): 137-156.

Aritonang, M. W. 2017. Kecenderungan Pemotongan Sapi dan Kerbau Betina Produktif di Provinsi Jambi. Jurnal Ilmiah Ilmu-Ilmu Peternakan. 20(1): 17-24. DOI: https://doi.org/10.22437/ jiiip.v20i1.4063.

Cadmus, S. I. B., and H. K. Adesokan. 2010. Bovine fetal wastage in Southwestwrn Nigeria: a survey of some abattoirs. Trop Anime Health Prod. 42 : 617-621.

[Dirjen] Direktorat Jenderal Peternakan dan Kesehatan Hewan. 2019. Pedoman Pelaksanaan UPSUS SIWAB, Upaya Khusus Percepatan Peningkatan Populasi Sapi dan Kerbau Bunting. Jakarta: Kementerian Pertanian Direktorat Jenderal Peternakan dan Kesehatan Hewan RI.

Dwiyanto, K. 2011. Inovasi Pendukung Ternak Rakyat. Badan Penelitian dan Pengembangan Pertanian. Dalam: Sinar Tani Edisi 30 Maret - 5 April 2011, No. 3399 Tahun XLI, Jakarta.

Fayerni, P. O., and V. Muchenje. 2013. Maternal Slaughter at Abattoirs: History, Causes, Cases and the Meat Industry. Springerplus. 2: 125 .

Isnaenul, M. 2016. Implementasi UU No. 18 tahun 2009 Pasal 18 ayat 2 Tentang Pelarangan Pemotongan Sapi Betina Produktif di RPH Kota Makasar. [Skripsi]. Makasar: Fakultas Peternakan Universitas Hasanudin.

Krog, C. H., J. S. Agerholm, and S. S. Nielsen. 2018. Fetal Assessment for Holstein Cattle. Ploss On November 19.

Lyne, A. G. 1960. Pre-Nataln Gowth in Cattle.CSIRO, Division of Animal Physiologi, Parramatta, NSW. Australia.

Mao, W. H., E. Albrecht, F. Teuscher, Q. Yang, R. Q. Zhao, and J. Wegner. 2008. Growth and Breed-related Changes of Fetal Development in Cattle. Asian-Aust. J. Anim.Sci. 21(5): 640-647.

Mappigau, P., S. N. Sirajuddin., K. Kasim, V. Lestari, dan S. Rohani. 2012. Perilaku Sapi Potong dalam Penjualan Sapi Betina Produktif (Kasus Pada Sentra Produksi Sapi Bali di 
Sulawesi Tenggara). http://repository.unhas. ac.id. [29/08/2018].

Mossberger, K, and H. Wolman. 2003. Policy Transfer as a Form of Prospective Policy Evaluation: Challenges and Recommendations. Public Administration Review. 63(4): 428 - 440. DOI: $10.1111 / 1540-6210.00306$.

Priyanto, D. 2011. Strategi Pengembangan Usaha Ternak Sapi Potong Dalam Mendukung Program Swasembada Daging Sapi dan Kerbau Tahun 2014. Jurnal Litbang Pertanian. 30(3): 108-116.

Purba, H. J., dan P. U. Hadi. 2012. Dinamika dan Kebijakan Pemasaran Produk Ternak Sapi Potong di Indonesia Timur. Jurnal Analisis Kebijakan Pertanian. 10(4): 361-373.

Rasminati, N., S. Utomo, dan D. A. Riyadi. 2009. Pemotongan Sapi Betina Produktif di Rumah Potong Hewan di Daerah Istimewa Yogyakarta. Sains Peternakan. 7(1): 20-24.
Soejosopoetro, B. 2011. Studi Tentang Pemotongan Sapi Betina Produktif di RPH Malang. $J$. Ternak Tropika. 12(1): 22-26.

Swai, E. S., A. A. Hayghaimo, A. A. Hassan, and B. S. Mhina. 2015. The Slaughter of Increased Number of Pregnant Cows in Tanga Abattoir, Tanzania: A Cause for Concern?. Journal of Veterynary Research 82(1): 947-951.

Taylor, R. K., C. T. LeMaster, K. S. Mangrum, R. E. Ricks, and N. M. Long. 2017. Effect of Maternal Nutrien Restriction During Early or Mid-Gestation Without Realimentation on Maternal Physiology and Foetal Growth and Development in Beef Cattle. Animal. 12(2): 1-10. DOI: $10.1017 / \mathrm{S} 175173111700163 X$.

Tawaf, R., O. Rachmawan, dan C. Firmansyah. 2013. Pemotongan Sapi Betina Umur Produktif dan Kondisi RPH Di Pulau Jawa dan Nusa Tenggara. Prosiding Workshop Nasional : Konservasi dan Pengembangan Sapi Lokal. Fakultas Peternakan Unpad Bandung, 13 Nopember 2013. p. 1-14.

Available online at journal homepage: http://ojs3.unpatti.ac.id/index.php/agrinimal 